\title{
The genetic profile of maturity onset diabetes of the young (MODY) in Sri Lanka using next generation sequencing
}

\author{
N. Somasundaram ${ }^{1}$, N. Thomas ${ }^{2}$, A. Chapla ${ }^{2}$, A. Wijesinghe ${ }^{1}$, T. Wanigasekera ${ }^{1}$, P. Peiris ${ }^{1}$. \\ ${ }^{1}$ National Hospital of Sri Lanka, Diabetes and Endocrinology Unit, Colombo, Sri Lanka. \\ ${ }^{2}$ Christian Medical College, Department of Endocrinology- Diabetes and Metabolism, Vellore, India.
}

\section{Background}

MODY is characterized by early onset diabetes in patient and family, autosomal dominant inheritance and non-insulin dependence. Definitive diagnosis of MODY is vital to decide on personalized therapy and for family screening, which needs genetic categorization. The estimated prevalence of MODY is about $0.8-2 \%$ among diabetes patients which make it imperative to develop specific screening criteria to pick up those who are having highest pretest probability to be referred for genetic screening which is a technically demanding and expensive investigation.

\section{$\underline{\text { Aims }}$}

- Develop specific clinical and biochemical screening criteria for MODY to be referred for MODY genetic screening

- Gene mutations analysis for establishment of genetic mutations of MODY types in Sri Lankan population and family screening

\section{Methods}

Study Type: Cross Sectional Analytical study Sample Size:87 patients

Inclusion criteria:

- Onset of diabetes $<40$ years of age

- Presence of $\geq 2$ generation family history

- Absence of $\beta$ cell immunity (GAD antibody)

- No history of diabetes ketoacidosis

- Detection of measurable $\mathrm{C}$ peptide in the presence of hyperglycemia

- Low Insulin requirement $(<0.5 \mathrm{u} / \mathrm{kg} / \mathrm{d})$

Genetic screening:

- Next-Generation Sequencing (NGS) based strategy to screen 13 known MODY genes and the identified probable pathogenic mutations

- Variants were confirmed by Sanger sequencing

\section{$\underline{\text { Results }}$}

Out of the 82 patients screened, 15 were found to be carriers of MODY related genetic variants accounting for prevalence of $18 \%$ in our study sample.

The most common mutation was the PDX1 mutation accounting for MODY type 4 in 6 patients. There were 2 positive patients each in HNF1A (MODY 3), NEUROD1 (MODY 6) and ABCC8 (MODY 12) genes. There was one patient each with mutations in HNF4A (MODY 1), KLF11 (MODY 07) and BLK (MODY 11).
Out of the gene panels screened, 4 were novel mutations ( 2 in ABCC8 gene and one each in KLF11, HNF1A and PDX1 genes). ABCC8 c.695G >A was classified as pathogenic. ABCC8 c.2401G $>T$, HNF1A c.1135C $>T$ and PDX1 c.98C $>A$ were classified as likely pathogenic and KLF11 C.1120G >A as variant with uncertain significance (VUS).

\begin{tabular}{|c|c|c|c|c|c|c|c|}
\hline No & $\begin{array}{l}\text { Se } \\
x\end{array}$ & MODY Gene & Mutation & $\begin{array}{l}\text { AA } \\
\text { change }\end{array}$ & $\begin{array}{l}\text { MODY } \\
\text { Type }\end{array}$ & $\begin{array}{l}\mathrm{R} / \\
\mathbf{N}^{*}\end{array}$ & $\begin{array}{l}\text { ACMG } \\
\text { Classification }\end{array}$ \\
\hline 1 & $\mathrm{~F}$ & ABCC8 & c. $695 \mathrm{G}>\mathrm{A}$ & p. V232X & MODY 12 & $\mathrm{~N}$ & Pathogenic \\
\hline 2 & $\mathrm{~F}$ & $\mathrm{ABCC} 8$ & c. $2401 \mathrm{G}>\mathrm{T}$ & p. V801F & MODY 12 & $N$ & $\begin{array}{l}\text { Likely } \\
\text { pathogenic }\end{array}$ \\
\hline 3 & M & PDX1 & c. $670 \mathrm{G}>\mathrm{A}$ & p. E224K & MODY 4 & $\mathrm{R}$ & $\begin{array}{l}\text { Likely } \\
\text { pathogenic }\end{array}$ \\
\hline 4 & $\mathrm{~F}$ & PDX1 & c. $670 \mathrm{G}>\mathrm{A}$ & p. E224K & MODY 4 & $\mathrm{R}$ & $\begin{array}{l}\text { Likely } \\
\text { pathogenic }\end{array}$ \\
\hline 5 & $\mathrm{~F}$ & PDX1 & c. $670 \mathrm{G}>\mathrm{A}$ & p. E224K & MODY 4 & $\mathrm{R}$ & $\begin{array}{l}\text { Likely } \\
\text { pathogenic }\end{array}$ \\
\hline 6 & $\mathrm{~F}$ & NEUDOD1 & c. $723 C>G$ & p. $\mathrm{H} 241 \mathrm{Q}$ & MODY 6 & $\mathrm{R}$ & $\begin{array}{l}\text { Likely } \\
\text { pathogenic }\end{array}$ \\
\hline 7 & $\mathrm{~F}$ & BLK & c. $833 C>T$ & p. P278L & MODY 11 & $\mathrm{R}$ & VUS \\
\hline 8 & $\mathrm{~F}$ & HNF4A & $\begin{array}{l}\text { c. } 505 G>A \\
\text { c. } 493-4 G>A \\
\text { c. } 493-20 C>T\end{array}$ & $\begin{array}{l}\text { P. } \\
\text { Val169lle }\end{array}$ & MODY1 & $\mathrm{R}$ & $\begin{array}{l}\text { Likely } \\
\text { pathogenic }\end{array}$ \\
\hline 9 & $\mathrm{~F}$ & HNF1A EX3F & c. $703 \mathrm{G}>\mathrm{C}$ & p.E235Q & MODY 3 & $\mathrm{R}$ & Pathogenic \\
\hline 10 & $\mathrm{~F}$ & PDX1 EX2F & c. $670 G>A$ & p.E224K & MODY 4 & $\mathrm{R}$ & $\begin{array}{l}\text { Likely } \\
\text { pathogenic }\end{array}$ \\
\hline 11 & $\mathrm{~F}$ & PDX1 EX2F & c. $670 \mathrm{G}>\mathrm{A}$ & p.E224K & MODY 4 & $\mathrm{R}$ & $\begin{array}{l}\text { Likely } \\
\text { pathogenic }\end{array}$ \\
\hline 12 & $\mathrm{~F}$ & KLF11 EX3R & c. $1120 G>A$ & p.V374M & MODY 7 & $\mathrm{~N}$ & VUS \\
\hline 13 & $\mathrm{~F}$ & HNF1A EX6F & c. $1135 C>T$ & p.P379s & MODY 3 & $N$ & $\begin{array}{l}\text { Likely } \\
\text { pathogenic }\end{array}$ \\
\hline 14 & $\mathrm{~F}$ & PDX1 EX1F & c. $98 \mathrm{C}>\mathrm{A}$ & p.P33H & MODY 4 & $\mathrm{~N}$ & $\begin{array}{l}\text { Likely } \\
\text { pathogenic }\end{array}$ \\
\hline 15 & M & $\begin{array}{l}\text { NEUROD1 } \\
\text { EX2AF }\end{array}$ & c. $175 G>C$ & p.E59Q & MODY 6 & $R$ & VUS \\
\hline
\end{tabular}

* N- Novel mutation, $\mathrm{R}$ - Reported mutation

\section{Discussion}

The specific criteria we have used to select patients for MODY screening has yielded a prevalence value of $18 \%$ and it can be used as future screening model. Few of the PDX1 gene variants based on the ExAC has been suggested that these variants could be benign. However, these variants are consistently very rare with a MAF $<0.001$ and have shown to functionally impact the normal function of the PDX1 protein. Therefore, PDX1 variants such as E224K are a strong candidates for a pathogenic variant in Sri Lankan patients. The genetic characterization of MODY patients in Sri Lanka is quite different from European population where the most common mutation is HNF $1 \mathrm{~A}$ mutation whereas in ours it is PDX1. 